\title{
Land Degradation Neutrality Assessment using Geospatial Techniques in North Wello Zone, Northern Ethiopia \\ Getnet Zeleke Tessera, ${ }^{1}$ Menberu Teshome(P.hD $)^{2}$ and Linger Ayele(P.hD) ${ }^{3}$
}

1. Department of Geography and Environmental Studies, University of Gondar, Ethiopia Email: getnetzelke@gmail.com (correspondence author)

2. Department of Geography and Environmental Studies, Debretabor University, Ethiopia Email: menberuteshome@gmail.com

3. Department of Geography and Environmental Studies, University of Gondar, Ethiopia Email: lingua1989@gmail.com

\begin{abstract}
Land degradation a serious and nationwide environmental concern in Ethiopia. The problem is its iterative relationship between land degradation, climate change, and agriculture, exacerbating one another via negative and positive feedback loops. Due to the need for an efficient response to land degradation in the country, different sustainable land management practices have been implemented since the late 1980s. The objective of this study was to analyze land degradation neutrality status using remote sensing data in the study area. We have studied the land degradation neutrality conditions of the North Wello Zone by using indicators data, namely land cover change, land productivity dynamics, and soil organic carbon stock. The result shows that the settlement areas consistently expanded at the fifth speed (2010-2018) from 1995 to 2010. Between 1995 and 2010, forestland declined by 18 percent, while an increasing trend of 26.8 percent from 2010 to 2018. The assessment results also indicate that 52.8 percent of the total area is stable and characterized by less stressed land productivity. The soil organic carbon is comparatively abundant in the high and midland vegetation areas but very thin in lowland areas. Most of the highland and midland parts of the study areas are in the conditions of stable and increasing land productivity with high biomass and soil organic content. However, most lowland areas showed a decline in land productivity conditions.
\end{abstract}

Keywords: Land Degradation, Land Productivity Dynamics, Vegetation Cover Change, Soil Organic Carbon 


\section{Background}

Land is a component of Mother Nature serving as infrastructure for much of life on earth (Safriel, 2007), which provides the principal basis for human livelihoods and well-being, which includes the supply of food, freshwater, and multiple other ecosystem services as well as biodiversity (IPCC, 2019). As to the Millennium Ecosystem Assessment (MEA, 2005), the term 'land' encompasses renewable natural resources, such as soils, water, vegetation, and wildlife, in their terrestrial ecosystems. Land Scientists estimated that about $11 \%$ of the global land surface is prime land, yet this must feed the 6 billion people inhabiting the world today and the 8.2 billion people expected by the year 2020 (Sivakumar \& Ndiang, 2007). During 2013, $37 \%$ of the earth's landmass, except Antarctica, cultivated to grow food, $12 \%$ as croplands and $25 \%$ as grazing lands (Searchinger et al., 2013). The estimations show that the world population will increase from 6.9 billion people today to 9.1 billion in 2050 . Food production will increase by $70 \%$ worldwide and by $100 \%$ in developing countries (FAO, 2011). Food production systems, especially in Africa, face enormous challenges in land degradation and climate change problems (Winterbottom, 2013).

Land degradation and climate change pose enormous risks to global food security (Webb et al., 2017). According to Hurni et al. (2010), the term land degradation refers to all processes that diminish the capacity of land resources to perform essential functions and services in terrestrial ecosystems, due to deforestation, loss of biodiversity, soil degradation, and disturbance of water cycles. Climate change and land degradation have an iterative relationship, driving or exacerbating one another through positive and negative feedback loops (Reed et al., 2016). The quality of the land can be influenced by climatic factors and the deterioration of land conditions, in turn, has been shown to have an impact on the atmosphere and future climate (Henry et al., 2007). Land degradation increases the vulnerability of agroecological systems to climate change and reduces the effectiveness of adaptation options (Webb et al., 2017). The relationship between agriculture and land degradation may be conflicting (win-lose) or synergistic (win-win) (Tengberg \& Torheim, 2007). A win-lose relationship occurs when agricultural activities are driven by land degradation and climate change (IPCC, 2007). For instance, increased food production through extensification or the use of more inorganic inputs may cause land degradation and climate change. However, the loss and degradation of soil and vegetation significantly reduce potential carbon sinks (FAO, 2013). A synergistic approach, on the other hand, occurs when sustainable agricultural production and land degradation neutrality can be achieved simultaneously (FAO, 2013).

According to the FAO (2011), land and water systems are declining their productive capacity due to high population pressure and unsustainable agricultural practices (FAO, 2011). The physical limits to land and water availability within these systems may be further exacerbated by land-use change, land-use intensification, and climate change (IPCC, 2019). Climate change can exacerbate and accelerate land degradation through various means, including accelerated soil erosion, increased evapotranspiration rates, drought, and changes in biodiversity, pests, and diseases (Webb et al., 2017). On the other hand, land degradation is a threat to natural resources, resulting in food security, poverty, and environmental and political stability (Sivakumar \& Ndiang, 2007).

Long-term food productivity is threatened by soil degradation, especially in Sub-Saharan Africa (Sivakumar \& Ndiang, 2007). The World Bank estimation shows that at least 485 million Africans are affected by land degradation, and Africa costs a US $\$ 9.3$ billion annual cost due to this phenomenon (Thiombiano \& Tourino-Soto, 2007). In Ethiopia, land degradation is one of the most challenging problems (Badege, 2001; Hurni et al., 2010; Mekuria et al., 2007; Taddese, 2001; 
Teketay, 2001). The most frequently cited causes of land degradation in Ethiopia are population pressure, soil loss through erosion, deforestation, land use change, overgrazing, overcultivation, and climate change(drought) (Holden \&Shiferaw, 2004; Hurni et al., 2010; Taddese,2001; Teketay, 2001). As a cumulative effect of land degradation, increasing population pressure, and low agricultural productivity, Ethiopia has become increasingly dependent on food aid (Kassie et al., 2010).

Recognizing this urgent need for an efficient response to land degradation, climate change, and food security in the twenty-first century, united nations conventions on combating desertification (UNCCD) proposed the concept of land degradation neutrality. According to Kust et al. (2017), land degradation neutrality is a state of equilibrium in land systems (Kust et al., 2017). It represents an urgent and comprehensive action to address degradation (Okpara et al., 2018). The aspirational goal of a land degradation neutral world, to be realized by reducing the rate of land degradation and increasing the restoration of degraded land, was agreed at the Rio +20 Conference in 2012(Grainger, 2015). One of the Africa Consensus Statements to Rio+20 in sustainable development goals is achieving zero net land degradation and the target of food security and poverty eradication (UNCCD, 2012). The scientific community asserted that sustainable land management is one of the mechanisms for achieving land degradation neutrality (LDN) (Sanz et al., 2017). This is because land management practices can contribute significantly to climate change mitigation through carbon sequestration and improve land productivity and production (UNCCD, 2015).

For the last three decades, the government of Ethiopia and non-governmental organizations has undertaken a massive program of natural resource conservation to reduce environmental degradation (Kassie et al., 2010). In Northern Ethiopia, significant natural resource rehabilitation and development work was implemented between the mid-to-late 2000s within the framework of the Productive SafetyNet Program (PSNP) and under Managing Environmental Resources to Enable Transition (Abera et al., 2019).

Studies in Ethiopia have demonstrated that existing management has contributed to improved native vegetation composition and diversity, above-ground biomass, land cover, soil quality, and an increase in ecosystem carbon stocks (Abegaza et al., 2020; Damene et al., 2013; 2020; Girma et al.,2020; Meaza et al., 2016; Mekuria et al.,2007; Temesgen, 2015; Shine, 2012). This study adds value to the growing literature on the trends of land productivity dynamics, which may indicate loss or degradation as well as the restoration of land and soil quality. The uniqueness of the current study from the above vast literature presents the land productivity dynamics trends based on the evaluations of land degradation neutrality assessment tools employed by UN indicators under one umbrella. Therefore, the primary aim of this study was to analyze the status of in land degradation neutrality in the North Wello Zone, Northern Ethiopia. 


\section{Materials and Methods}

\subsection{Study site description}

This study was conducted in the northeastern parts of the Amhara Regional states, particularly in the North Wello zone. The capital of North Wello was Woldia. The area is located between $11^{\circ} 30^{\prime} 0^{\prime \prime}$ and $12^{\circ} 30^{\prime} 0^{\prime \prime} \mathrm{N}$ latitude and $38^{\circ} 30^{\prime} 0^{\prime \prime}$ to $40^{\circ} 0^{\prime} 0^{\prime \prime}$ ' E longitude.

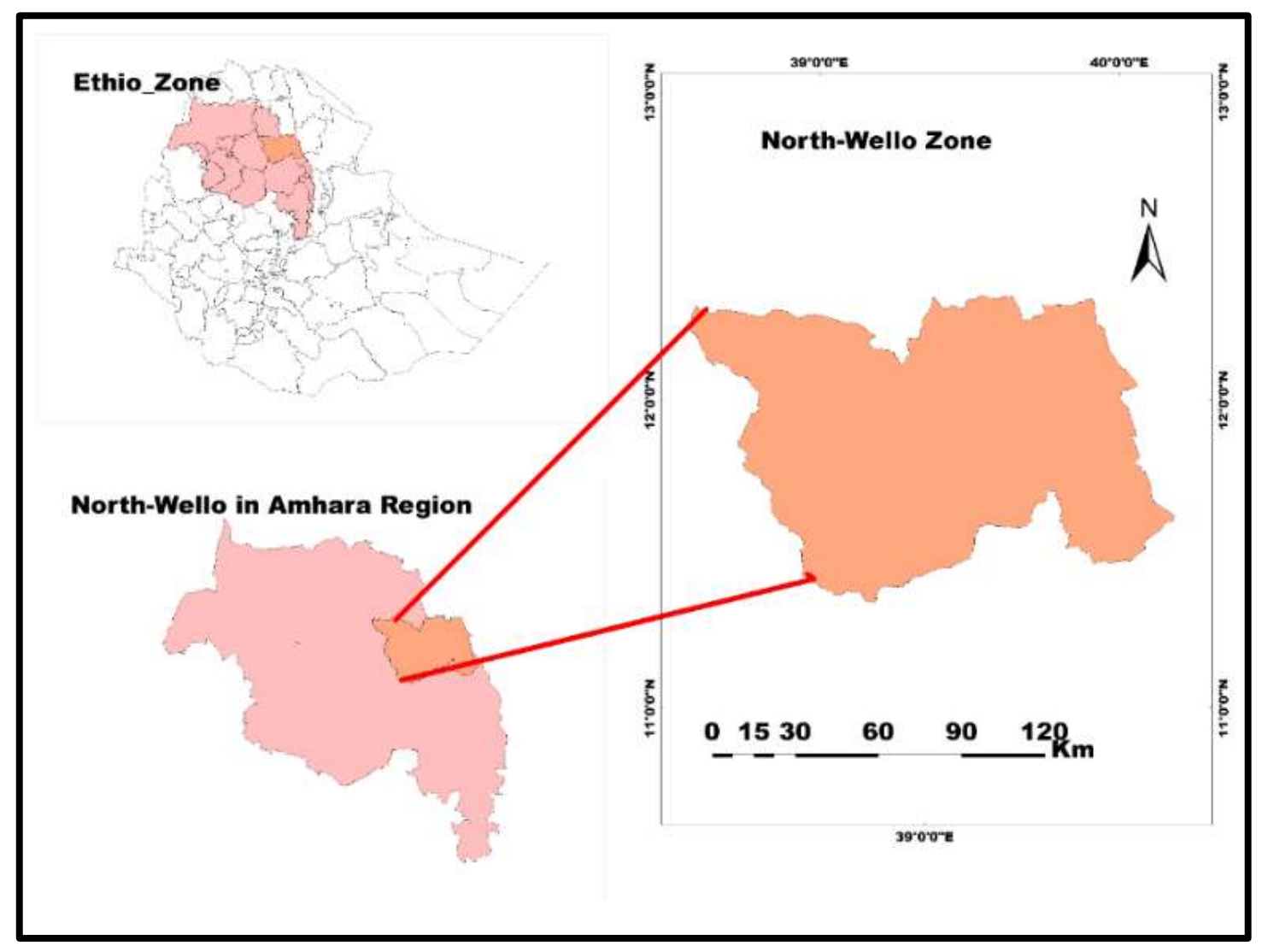

Figure 1: Location of study area

The elevation in this study area ranges from 960 to $4265 \mathrm{~m}$ above the mean sea level. The highest and lowest altitudes in the North Wello Zone are located in the Lasta and Habru districts, respectively. The relief differences would have a significant influence on the climate, soil, and biota variations across the area. The majority of areas are steep slopes (15\%-30 gradient) to extremely steep slopes (30\%-60 gradient) covering $25.15 \%$ and $36.06 \%$ of the total area, respectively. As suggested by Hurni (1988), land with slopes of less than $15 \%$ is the most suitable for agriculture. However, this area accounted for only $31 \%$ of the total area.

In the study area, the monthly temperature averages in the study area for the last 40 years (19792020) ranged from $16^{\circ} \mathrm{C}$ in December to $20^{\circ} \mathrm{C}$ in May. Its 40 years (1979-2020) monthly maximum temperature averages also range from $25^{\circ} \mathrm{C}$ in December to $29^{\circ} \mathrm{C}$ in May. The minimum monthly temperature average recorded in the same time range is $7{ }^{\circ} \mathrm{C}$ in December to $12^{\circ} \mathrm{C}$ in May. In the study area, the temperature throughout the year showed little variation, roughly from 3 to $6^{\circ} \mathrm{C}$ from the warmest month (between April and June) to the coldest month (between November and February). The hottest period was March to May, before the onset of the main rainy season. The 
variation in temperature and rainfall due to the effect of altitude in this region is significant (Conway, 2000).

The maximum Mean Monthly Precipitation averages (mm) were 363.9 in August, and the minimum Mean Monthly Precipitation averages (mm) 18.4 in November (Figure 2). According to Ethiopia's National Meteorological Service Agency, the main precipitation of Ethiopia produced was in July and August, with the peak rainfall falling in late July and before mid-August. The annual average precipitation ranges from 800 to $1,200 \mathrm{~mm}$ ).

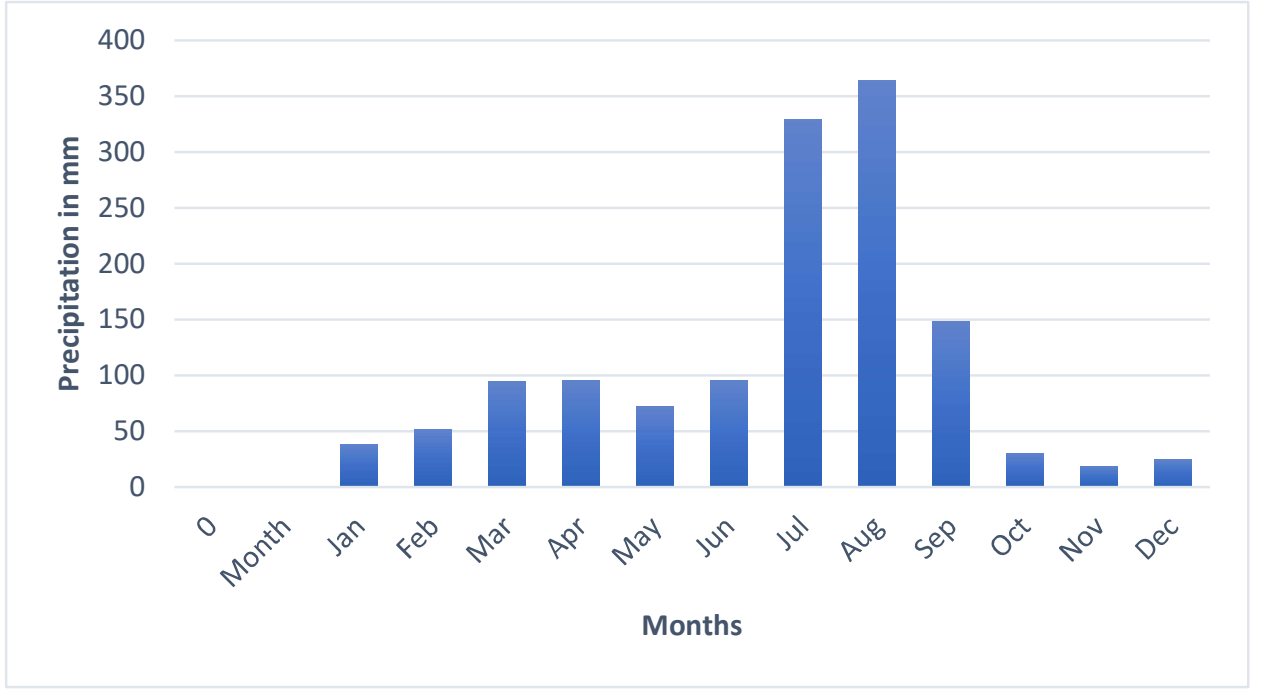

Figure 2: Mean Monthly precipitation of North Wello (1979-2020)

The diversity in climate, topography, and vegetation in the area has given rise to marked variations in soils, even within relatively small areas (Eliays, 2000). In the highlands of Wello, there are various soil types, such as Cambisols, Luvisols, Vertisols, Xerosols, Leptosols, Regosols, and Nitisols. Cambisols are the dominant soil types in the study area, accounting for $46 \%$ of the total area. These soils are found in Colluvial materials and on moderate to steep slopes. Orthic Luvisols cover $12 \%$ of the total area of the North Wollo Zone. Chromic vertisols accounted for $9 \%$ of the total area. Haplic Xerosols cover $7 \%$ of the total study area, particularly in the semi-arid parts of the area. Eutric Regoslos covers $6 \%$ of the total area of the North Wollo Zone.

\subsection{Indicator Data Source and Analysis}

To assess the land degradation neutrality status, three global indicators that are in current use by the United Nations conventions on combating desertification (UNCCD,2016) and recently proposed in the use of evaluating land degradation neutrality were provided to countries. Indicator data used in this analysis were: land use/land cover changes over the period 1995 to 2018, land productivity dynamics over the period of 2001 to 2017, and soil organic carbon for 2019 . The methods are described in land degradation neutrality target setting technical guide (UNCCD, 2016).

\section{Land Cover Change}

For this study, the multi-temporal land cover map classified based on the IPCC Land use classification method on climate change initiatives (CCI data) was downloaded from earthmap.org website in Tiff format. The classification of land use classes was classified based on the Google 
Earth Engine and available with a complete legends and statistics. The percentages of land use/land cover change were calculated using the following formula:

Percentage LU/LC Change $=\frac{\text { Area of Final Year }- \text { Area of Initial year }}{\text { Area of Initial Year }} \times 100$

Positive values indicate an increase whereas negative values show a decrease in the extent of LU/LC.

\section{NDVI Change and Land Productivity Dynamics}

NDVI is an indicator of vegetation health. The determination of normalized difference vegetation index (NDVI) value was by using the near-infrared (NIR) and visible reflectance bands. Thus, NDVI is calculated as $: N D V I=\frac{N I R-R}{N I R+R}$, Where NDVI $=$ normalized difference vegetation index, NIR = reflection from near infrared wavelength region, RED $=$ reflection from red wavelength region. In the Earth map platform, the vegetation indices such as NDVI was derived from MOD13A1 v006 MODIS/Terra Vegetation Indices 16-Day L3 Global $500 \mathrm{~m}$ SIN Grid and available from 2000 to 2020 . The MOD13A1 vegetation indices were generated from a spatial resolution of $250 \mathrm{~m} \times 250 \mathrm{~m}$ pixel size and 16 days temporal resolutions. Thus, the current study employed this processed data to interpreted and analyzed the vegetation cover change in the North Wello zone.

Low values of NDVI ( 0.1 and below) correspond to barren areas of rock, sand, or snow. Moderate values represent shrub and grassland (0.2 to 0.3$)$, while high values indicate temperate and tropical rainforests (0.6 to 0.8). Based on Nega et al. (2019), satellite images with an NDVI $>0.45$ were classified as vegetated and pixels with a value $<0.45$ were classified as non-vegetated areas. Land productivity dynamics is a map of persistent decline/stress, stability, and gain of land productivity, strictly during the observation period from 2001 to 2017 generated through the interaction of three NDVI-based indicators: steadiness, initial standing biomass, and standing biomass at change (https://earthmap.org/).

\section{Soil organic carbon density}

Soil organic carbon is also an indicator of soil quality (Kust et al., 2017). Studies show that soil conservation practices increase the capacity for long-term C sequestration (Hidalgo et al., 2019). Long-term fertilization with N, P, and K fertilizers (NPK) and combined manure (M) significantly increases the quantity of soil organic matter (Yang et al., 2011). Thus, to use soil organic content as an indicator of land quality change, we used a global soil organic carbon map prepared for the year 2019.

\section{Results and discussions}

\section{Land Use and Land Cover classifications}

The six major land use/ land cover types for the years 1995, 2000, 2010, and 2018(Figure 5) are presented based on the six IPCC land categories, with: cropland, forest, grassland, wetland, settlement, and others. These latter land categories further split into shrub land, sparse vegetation, bare area, and water. The total area of the North Wello Zone is 1222152 ha. The land use/ land cover class area and their percentages for 1995, 2000, 2010, 2015, and 2018 are presented in Table (1). 


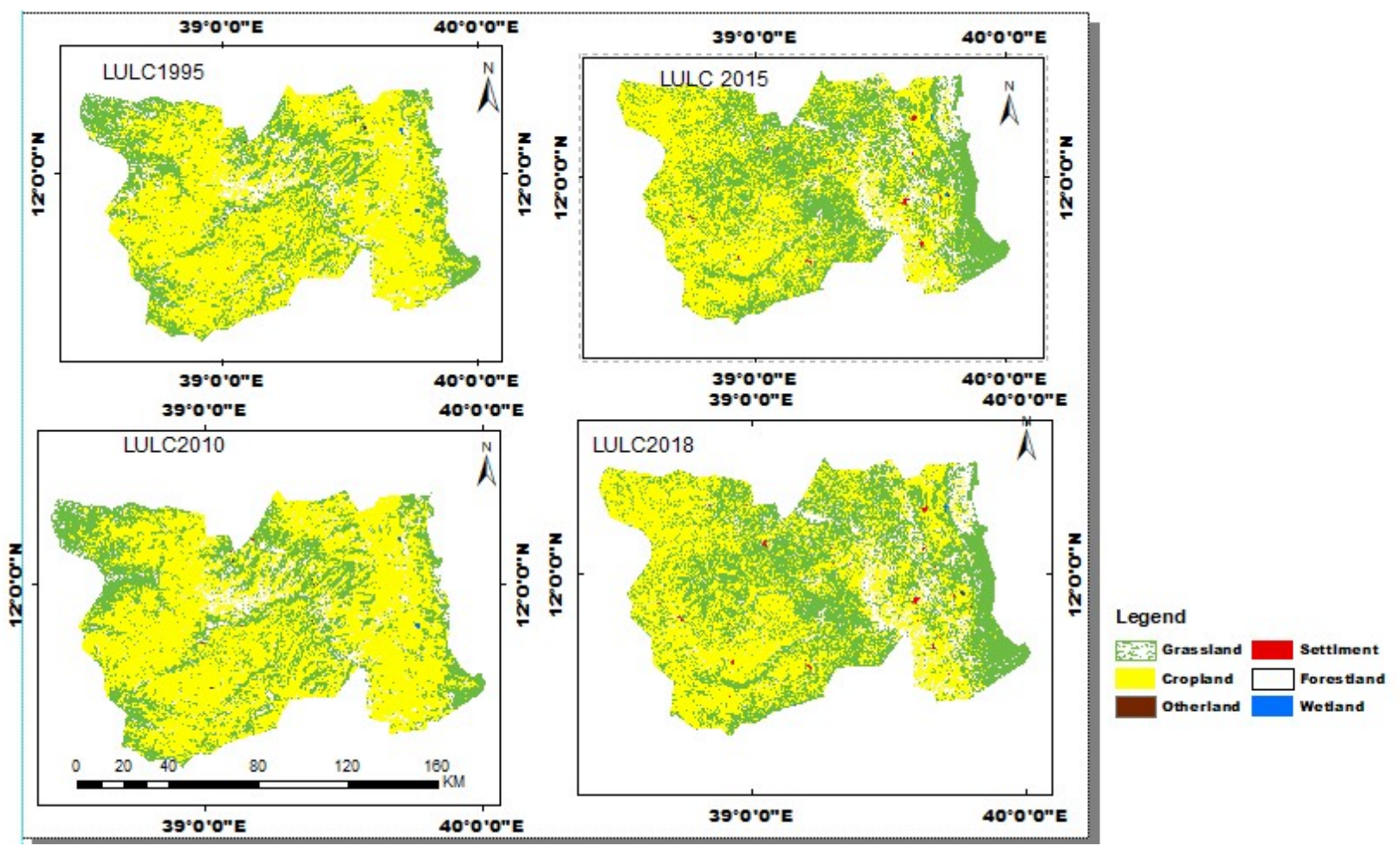

Figure 3: Land Use/ Land Cover Class of North Wello Zone (for the year 1995, 2000, 2010 and 2018). Source: https://earthmap.org/?aoi=et\&boundary=level2.

Table1: Land use/ land cover classes and percentage.

\begin{tabular}{|c|l|l|c|c|c|c|c|c|}
\hline $\begin{array}{c}\text { Land Use } \\
\text { Type }\end{array}$ & 1995 & $\%$ & 2000 & $\%$ & 2010 & $\%$ & 2018 & $\%$ \\
\hline Forest & 68387.2 & $\begin{array}{c}5.59563 \\
8\end{array}$ & 68457.19 & 5.601365 & 59530.24 & 4.870934 & 75458.23 & 6.174208 \\
\hline Cropland & $\begin{array}{c}766908 . \\
7\end{array}$ & $\begin{array}{c}62.7506 \\
8\end{array}$ & 763799.6 & 62.49629 & 771521.2 & 63.12807 & 763576.2 & 62.47799 \\
\hline Settlement & 420.1 & $\begin{array}{c}0.03437 \\
4\end{array}$ & 472.61 & 0.03867 & 481.37 & 0.039387 & 866.61 & 0.070909 \\
\hline Grassland & $\begin{array}{c}357790 . \\
2\end{array}$ & $\begin{array}{c}29.2754 \\
3\end{array}$ & 360776.8 & 29.5198 & 362261.9 & 29.6413 & 353955 & 28.96161 \\
\hline Wetland & 1312.27 & $\begin{array}{c}0.10737 \\
4\end{array}$ & 1312.27 & 0.107374 & 1023.74 & 0.083765 & 1023.74 & 0.083765 \\
\hline Other land & 27333.9 & $\begin{array}{c}2.23653 \\
8\end{array}$ & 27333.9 & 2.236538 & 27333.9 & 2.236538 & 27272.54 & 2.231517 \\
\hline
\end{tabular}

Source: https://earthmap.org/. 


\section{Land Use/ Land Cover change}

From 1995 to 2010, settlement, grassland, and cropland areas increased by 61.5 hectares (14.6\%), 4471.7 hectares $(1.3 \%)$, and 4612.5 hectares $(0.6 \%)$ of the total area, respectively. In contrast, forest and wetlands decreased by 8856.96 hectares (13\%) and 288.5 hectares $(22 \%)$, respectively. Between 2010 and 2018, the area of forest and settlement increased by 15928 ha (28.8\%) and 385.24 ha $(80 \%)$, respectively, while grassland, cropland, and other lands (shrub land, sparse vegetation, bare area, and water) reduced by 8306.9 ha $(2.3 \%), 7945$ ha $(1.03 \%)$, and 61.4 ha $(0.22 \%)$, respectively (Table 2$)$.

In the study area, LULC changes showed temporal variability. For example, the areas of settlement consistently expanded at the fifth speed (2010-2018) from 1995 to 2010 . This result is consistent with the findings of other studies (Tolessa et al., 2017; Haregeweyn et al., 2012). Most recently, in response to the growing demand for housing and other urban activities, local governments initiated the process of annexing rural land into urban areas through a series of legislative actions (Wubneh, 2018). In Ethiopia, the expansion of settlement areas is at the expense of cultivable land. The peri-urban area is the center where this change is undertaken due to changes in land-use patterns, property rights, and loss of agricultural land. The transformation of agricultural land to urban areas has significant ecological, socio-economic, and environmental impacts.

Between 1995 and 2010, forest land declined by 8856.96 hectares (13\%), while it indicated an increasing trend of 15927.99 hectares $(26.8 \%)$ from 2010 to 2018 . This increase may be due to the closure of mountainous areas. This result is more likely with the findings of Shine (2012) in the Wello area and Bewket (2002) Chemoga Watershed, Blue Nile Basin of Ethiopia. However, this contradicts the reports by Belay and Mengistu (2019) in the Muger Watershed, Upper Blue Nile; Bewket \& Abebe (2013) in Ethiopian highland Watershed of Blue Nile; Berihun et al. (2019) in drought-prone areas of Ethiopia. The increase in forest cover in this study area may be due to Ethiopia's PSNP conducting land management interventions on approximately 600,000 ha (Woolf et al.,2018), which could have the potential to reduce greenhouse gas (GHG) emissions and sequester carbon in biomass and soils.

Other significant land-use changes in the study area also occurred in wetlands. The Wetlands declined by 288.53 hectares $(21.98 \%)$ from 1995 to 2010; whereas zero-net degradation was observed from 2010 to 2020 . The wetland area is naturally available as shallow lakes in the eastern parts of the study area near the towns of Hara and Kobo. However, nowadays their availability is critically threatened. For the causes of wetland reduction in the area, we believe that the combined effect of land use changes of uplands and climate change are prominent as they can affect the water budget. Most recently, the community-based watershed development programs in the study area have saved it from further degradation.

Besides, between 1995 to 2010, cropland and grassland show an increasing trend but decreasing trends were detected between 2010 and 2018 time period. Although the change was small (61.4 ha) or $0.22 \%$ of the shrubland, sparse vegetation, bare area, and water changed negatively after 2010 . 
Table 2: Land use/land cover change during (1995-2010 and 2010- 2018)

\begin{tabular}{|l|l|l|l|l|}
\hline $\begin{array}{l}\text { Land } \\
\text { Type }\end{array}$ & $\begin{array}{l}1995-2010 \\
\text { Area (ha) }\end{array}$ & $\%$ & $\begin{array}{l}2010-2018 \\
\text { Area (ha) }\end{array}$ & $\%$ \\
\hline Forest & -8856.96 & -12.9512 & 15927.99 & 26.75613 \\
\hline Cropland & 4612.5 & 0.6014406 & -7945 & -1.02978 \\
\hline Settlement & 61.27 & 14.584623 & 385.24 & 80.02991 \\
\hline Grassland & 4471.7 & 1.2498106 & -8306.9 & -2.29306 \\
\hline Wetland & -288.53 & -21.98709 & 0 & 0 \\
\hline Other land & 0 & 0 & -61.36 & -0.22448 \\
\hline
\end{tabular}

Source: https://earthmap.org/.

\section{NDVI index and Soil Organic Carbon}

The NDVI is widely used to determine the production of green vegetation and understand vegetation changes. Because, it is an indicator for biomass and soil organic carbon concentration. In this study, we examined the vegetation change of North Wello Zone from 2002 to present. In the period between 2002 and 2020, the average annual minimum NDVI value of the study area was +0.30 recorded in 2013, and the average maximum NDVI value was +0.37 in 2019. Between 2000 and 2020, the monthly average NDVI during the dry months of Ethiopia (January and February) was +0.2 and +0.18 , respectively.

We also processed the MOD13A1 vegetation indices for only the month of January corresponding to the driest period from the spatial resolution of $250 \times 250 \mathrm{~m}$ pixel size and 16 days temporal resolutions for the year 2002, 2011, 2016, and 2020. The results show that interannual variations in the greenness of the area. For example, NDVI of 0.45-0.6 covers 156,325 ha (13\%), 40,412.5 ha $(3.3 \%), 68.137 .5$ ha $(5.6 \%)$, and $29,100 \mathrm{ha}(2.4 \%)$ of the total area for the year 2002, 2011, 2016 , and 2020 respectively. The results also show that a larger proportion of the area is sparsely vegetated. The NDVI values above 0.6 covers 11,969 ha (1\%), 881.25 ha $(0.07 \%), 2850$ ha $(0.2 \%)$ and 618.75 ha (0.05\%) of the total area for the year 2002, 2011, 2016 and 2020 respectively (Table $3)$.

Table 3 shows the most of the study area covered by the NDVI value ranges from 0.15 to 0.3 . It is an agricultural field which is ready for cropping.

Table 3: index value of vegetation in North Wello Zone

\begin{tabular}{|c|c|c|c|c|c|c|c|c|}
\hline \multirow{2}{*}{$\begin{array}{l}\text { NDVI } \\
\text { value }\end{array}$} & \multicolumn{2}{|l|}{2002} & \multicolumn{2}{|l|}{2011} & \multicolumn{2}{|l|}{2016} & \multicolumn{2}{|l|}{2020} \\
\hline & Area(ha) & $\%$ & Area(ha) & $\%$ & Area(ha) & $\%$ & Area(ha) & $\%$ \\
\hline$<0$ & 106 & 0 & 325 & 0.3 & 43.75 & 0 & 25 & 0 \\
\hline $0-0.15$ & 49169 & 4 & 2631.25 & 0.22 & 18168.8 & 1.5 & 34300 & 2.8 \\
\hline $0.15-0.3$ & 585463 & 48 & 808625 & 66.2 & 815450 & 66.7 & 885575 & 72.5 \\
\hline $0.3-0.45$ & 418806 & 34 & 369219 & 30.2 & 317444 & 26 & 272475 & 22.3 \\
\hline $0.45-0.60$ & 156325 & 13 & 40412.5 & 3.3 & 68137.5 & 5.6 & 29100 & 2.4 \\
\hline$>0.6$ & 11969 & 1 & 881.25 & 0.07 & 2850 & 0.2 & 618.75 & 0.05 \\
\hline
\end{tabular}


The annual average NDVI value in the study available on earth map.org platform shows that the minimum NDVI values occurring in the years between 2017 and 2020 was 0.2 , and the maximum annual average NDVI was 0.75 (Figure 4).

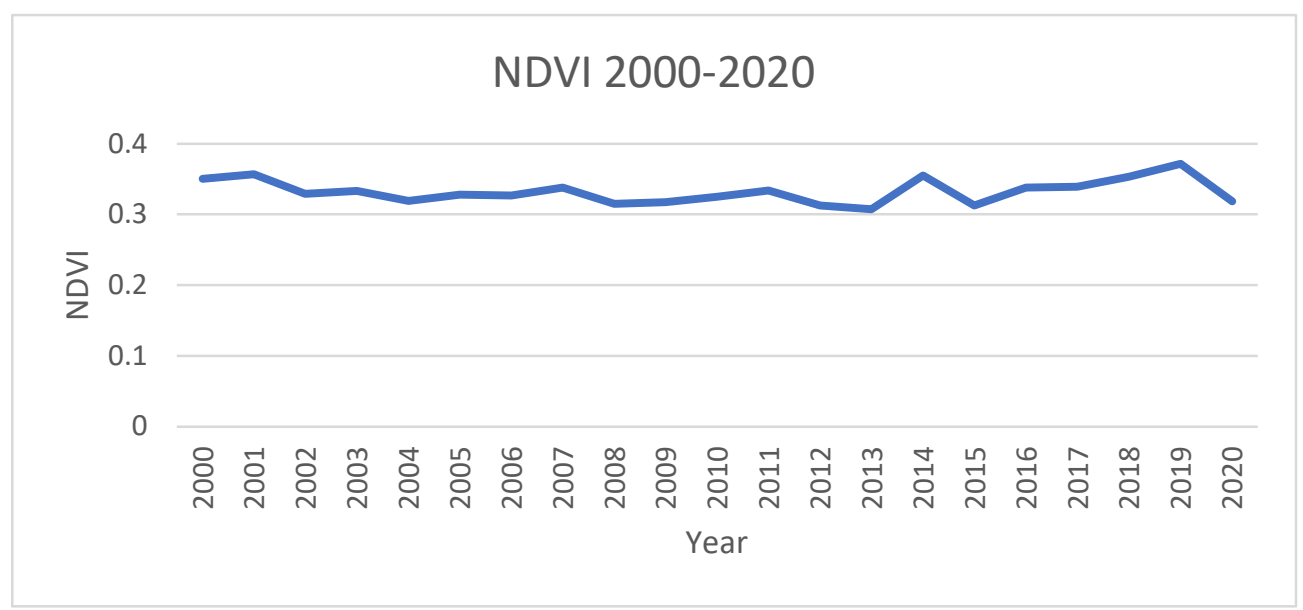

Figure 4: NDVI results for North Wello Zone

The lowest values were found in the less vegetated soils and seemingly because of the reflection from bare soils indicating small NDVI values. In a real sense, the values between 0.2 and 0.4 correspond to rainfed cropland and grasslands, and higher NDVI (above 0.4) are indicators of high photosynthetic activity linked to shrublands, Eucalyptus tree plantations, and forests in sloppy and mountainous areas of the North Wello Zone (Figure 5). Higher NDVI values help to identify the conditions of vegetation remaining green throughout the year, which indicates the effectiveness of land restoration programs. The NDVI for the forest with shading leaves in the drier season may not clearly show the real situation. In the study area, Dega (Highland) and Weynadega (Midland) areas show annual greenness dominated by evergreen species, while Kolla(lowlands) is dominated by Acacia species that flourish during the dry period (Figure 5). 


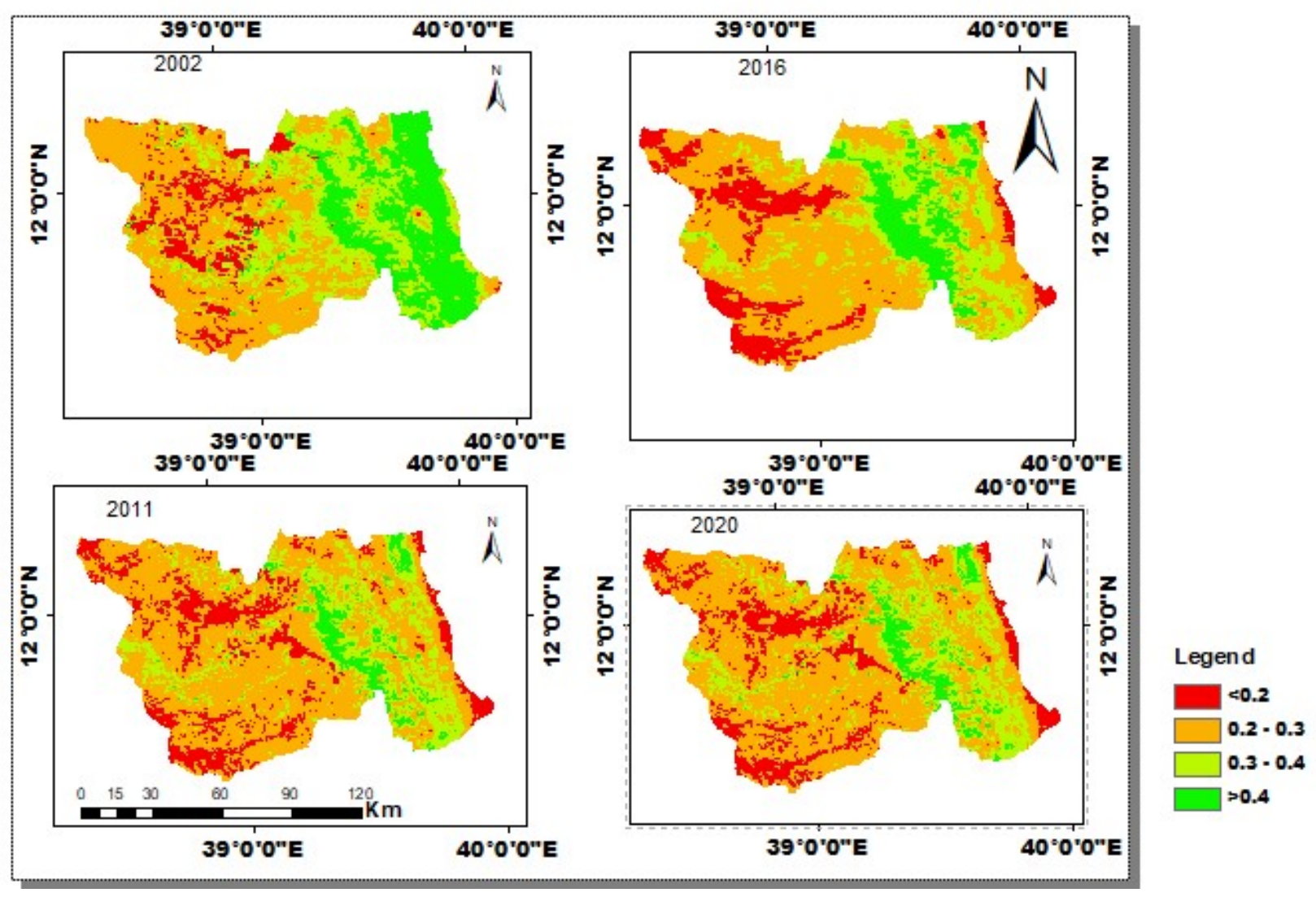

Figure 5: NDVI changes between 2002 and 2020 (January)

In this study, we used soil organic carbon as an indicator of land degradation neutrality. This is because soil organic carbon reflects slower changes from the net effects of biomass growth and disturbance/ removal indicating resilience of land (Cowie et al., 2018). We present the results obtained from the map of the global soil organic carbon in the earth map.org platform in Figure 6. The maximum and minimum soil organic matter measured at depth of $30 \mathrm{~cm}$ was 248.9 and 10 tons per hectare, respectively. The average soil organic carbon is 46 tons per hectare in the study area. The total amount of soil organic carbon estimated for this study area was 56,211,682 tons. Areal distribution of soil organic carbon is more prevalent on steep slopes and mountainous areas where the vegetation cover is high. In Figure 6 below, it is clear that soil organic carbon content is higher in forest areas of highlands than in the midland and lowland areas. The highlands of the North Wello zone are relatively higher annual NDVI values than the corresponding topographical positions. Hence, soil organic carbon is associated with the NDVI values in the study area.

The findings of this study are consistent with those of Abegaza et al. (2020), Abebe et al. (2020); Cha et al. (2020) and Girma et al. (2020) clearly show that soils of natural vegetation and protected areas of highlands contain the highest amount of SOC stock. As described in the land use categories above, the majority $(62 \%)$ is found to be cropland. However, previous studies (Abebe et al., 2020; Abegaza et al., 2020; Girma et al.,2020) show that soil carbon sequestration in croplands is small, which is also true in this study. Particularly in the highland areas, the SOC content in cropland was significantly increased from the upper to lower topographic positions 
(Abebe et al., 2020). This is because the upper lands are often exposed to soil erosion, serving as a source of runoff and sediment for the lower positions (Sun et al.,2015).

In most of the North Wello lowland areas, the natural vegetation is dominated by deciduous tree and shrub species that commonly contribute large amounts of organic matter to the soil. However, higher temperature and lower precipitation conditions, makes soil carbon production in this region may be slow (Figure 6). Empirically, this is true that SOC stocks generally increase as the mean annual temperature decreases (Stockmann et al., 2013). It has also been shown that less soil disturbance, greater vegetation cover, and organic input from grazing animals would improve the SOC in the highland areas (Abebe et al., 2020). The findings show the need for climate-smart land management practices that contribute to soil organic carbon stock and at the same time reducing its emission from croplands and grasslands of the study area.

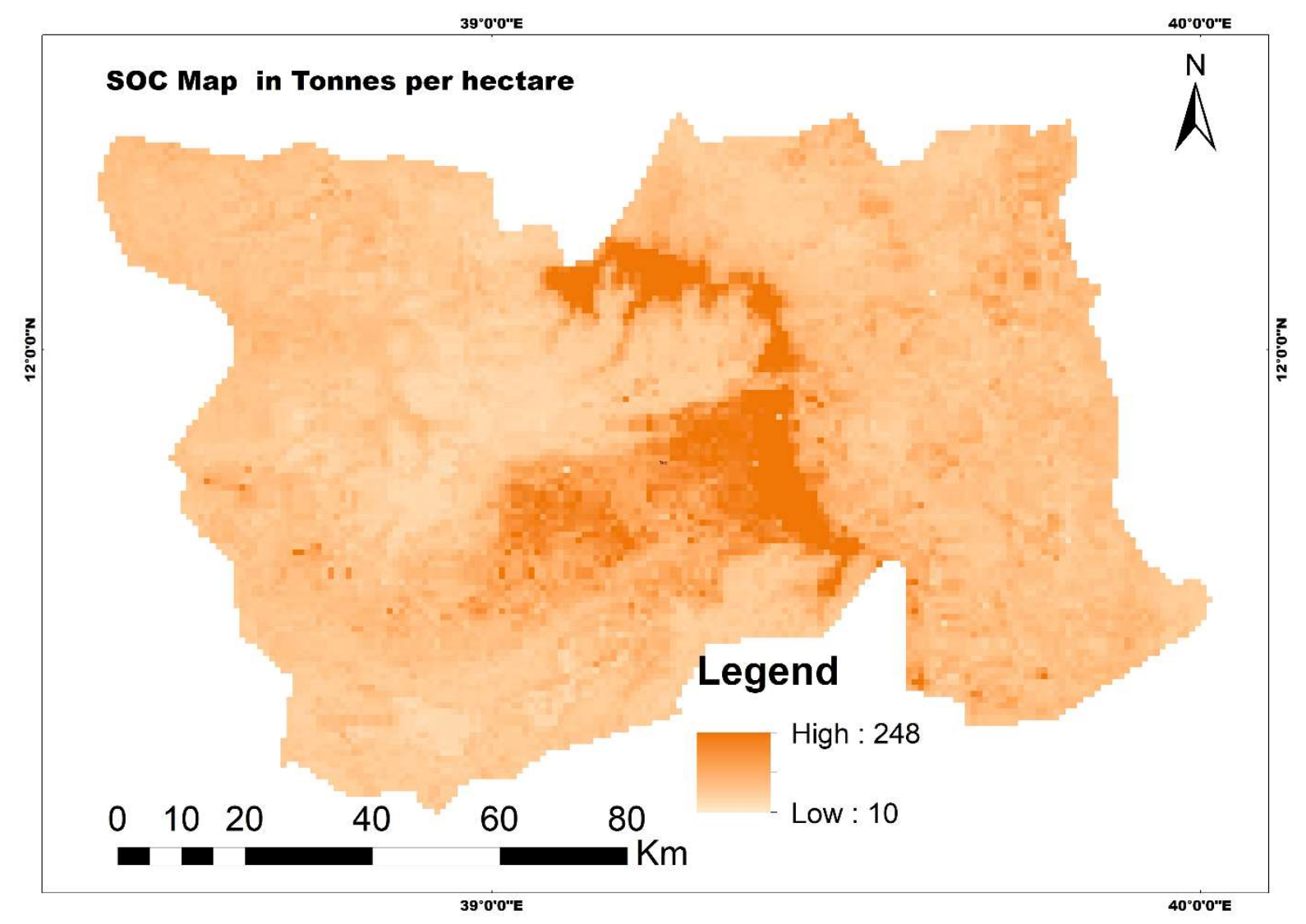

Figure 6: Soil organic carbon Map for North Wello Zone (2015). Source: earth map. Org

\section{Land Productivity Dynamics in North Wello Zone.}

In land-degradation neutrality contexts, the aims of RIO +20 are to protect productive land stable with sustained, or improved and maximized food production and other environmental services. Hence, land productivity is an indication of the level of sustainable land use, calculated as the relationship between land quality in general productive terms and what is obtained as output (Cherlet et al., 2013). To do so, the land productivity dynamics map is available from the earth 
map.org platform, which was produced for the period from 2001 and 2017, generated through the interaction of three NDVI-based indicators: steadiness, initial standing biomass, and standing biomass at change.

The FAO in the earth map.org platform produced a map that shows five classes of land productivity levels (Figure 7). In the North Wello Zone, 645, 520 ha (52.8\%) of its territory is stable with no stressed land productivity conditions. It has to be noted that land productivity levels vary according to land cover and land use types, but the overall productivity remained stable during 2001 to 2018. Appropriate agricultural land management, plantations and area closures of the sloppy lands are assumed. Naturally, the highland and midlands have relatively regular climate conditions, which can be assumed to have a positive effect on land productivity. In this regard, the previous finding by Damene et al. (2013) shows that the effect of microclimate on biomass production, vegetation types and organic matter mineralization are significant in the mild zone.

The other significant share of $277,269.5$ ha $(22.7 \%)$ of the land in the study area showed an increase in land productivity during the 2001 to 2018 period. The stable but stressed land productivity class is also covering 16,749 ha (1.2\%) of the total study area (Figure 7$)$. We assumed that land productivity is improving due to the natural resource rehabilitation and development work under the watershed management framework of PSNP in the study area through area closure and physical soil and water conservation practices. We suggest that conservation practices may not exclusively bring this positive trend, but also the micro-climate on biomass production, vegetation types, and organic matter mineralization plays a significant role in improving this trend, either positively or negatively.

Previous studies have reported that exclosures have contributed to vegetation restoration, improvement in soil nutrient status, reduced erosion, and increased land cover, soil fertility, water retention capacity, and ecosystem carbon stock (Damene et al.,2013; Damene et al.,2020; Meaz et al.,2016; Mekuria et al., 2007). According to Gashaw (2015), watershed management practices improve soil quality, vegetation cover, and crop production and productivity. The analysis also indicated that $(239,924.7$ ha $(19.64 \%)$ of the total land area of the North Wello Zone shows an early sign of decline or actual land productivity decline. About 42,389 ha (3.5\%) of the study area shows the declining trends of land productivity.

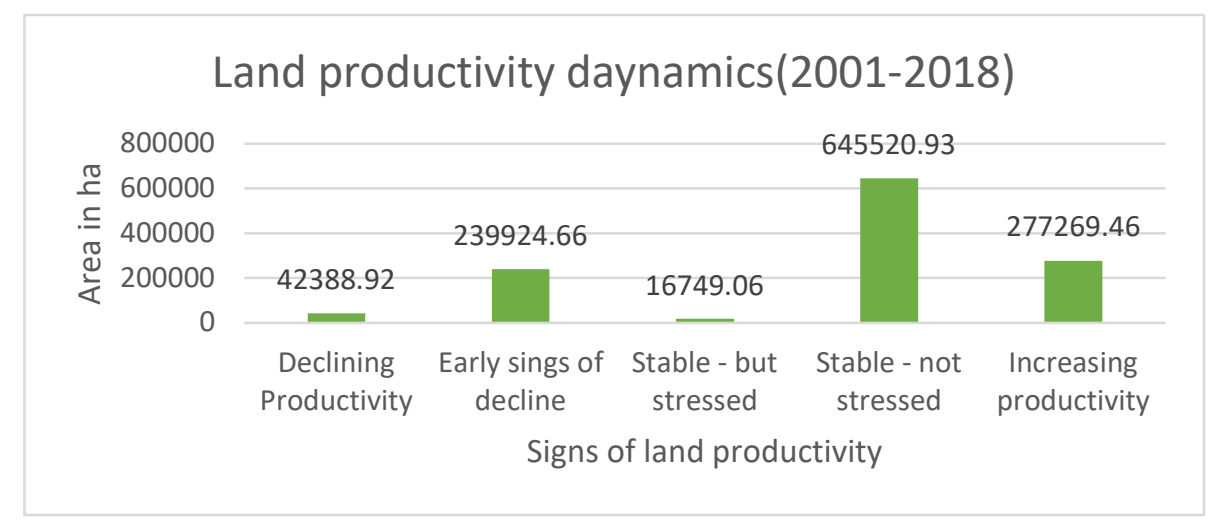

Figure 7: Land productivity signs in North Wello Zone for the period 2001 to 2018

The lowlands (Habru, Raya Kobo, and Bugna Districts) are with the land productivity decline (Figure 8). According to Cherlet et al. (2013), the decline or its early signs of land productivity may be due to climate extremes such as droughts or floods. In the current study, frequent droughts, 
over-cultivation, and overgrazing may contribute to declining land productivity. Temesgen et al. (2014) reported that population increase, severe soil loss, deforestation, and unbalanced crop and livestock productions causes for the declining of land productivity.

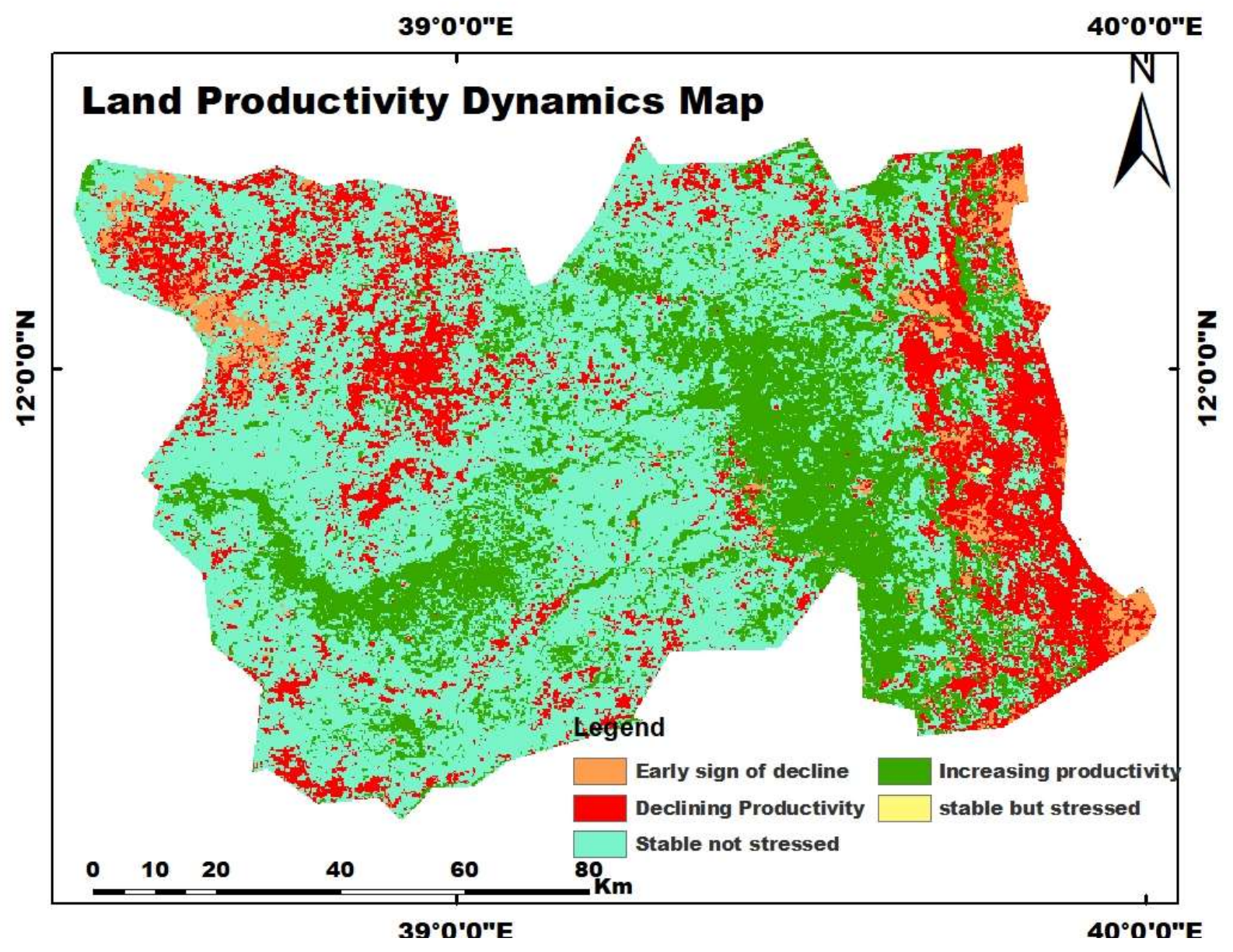

Figure 8: Land productivity Dynamics Map

\section{Discussion}

In the current study, we tried to evaluate the land degradation status based on land degradation neutrality indicators (UNCCD, 2016), based on the results described previously. Kust et al. (2017) defined land cover, productivity, and soil organic carbon which are used to measure land degradation. Cowie et al. (2018) one out, all out" rule states that an area is degraded if at least one of the three indicators shows a negative change. According to this rule, neutrality is the balance of losses and gains, each land-use type in the study area. In this study, we analyze the land use/land cover and land productivity dynamics and also soil organic carbon sequestration changes during 2000 to the present.

First, we consider the land use/ land cover change as an indicator of land degradation conditions. During the study period, significant land use was observed in the settlement expansion in the study area. This change is mainly through the conversion of arable land to settlement land in the study 
area. The encroachment of settlement lands into croplands may cause land quality loss. The expansion of built-up areas in the study area is mainly at the expense of agricultural lands that will have ecological and environmental impacts (Haregeweyn et al., 2012). The forest cover in the area also shows a positive change that may increase grass biomass and woody plant cover (Reid et al., 2000). The forest ground and canopy increased with exclosure age in the study area and showed spatial variation in biomass production and vegetation types. The midland seems green throughout the year, whereas greenness is seasonal in lowland where deciduous tree and shrub species dominate the ground cover. Thus, the seasonal microclimate conditions of the area strongly affect vegetation productivity and organic matter decomposition. In the current study, the land-use change analysis indicated that the quantity of cropland is going down. In the line of cropland studies, Reid et al. (2000) argued that the contraction of cropland increased grass biomass and vegetation cover. However, this argument is correct when cropland is converted to forest or agroforestry and other similar land-use types. In our cases, the contraction of cropland is mainly due to the expansion of settlement land that will negatively affect land productivity. The grassland in the study area shows temporal variations. Between 1995 and 2010, there was in an increasing trend. However, from 2010 to 2020, it was in a decreasing tendency. This pattern of change may be due to the current watershed development programs that are carried out with community participation. In these programs, many seedlings are planted annually in the grassland areas. Thus, community-based afforestation programs in the study area changed the age-old tradition of clearing steeper land for cultivation (Zeleke et al.,2001). The positive change in forest land and the net balance of wetlands in the year between 2010 and 2020 implying that watershed management shows encouraging impacts.

Second, land productivity was estimated using net primary productivity, NPP set by the United Nations Convention to Combat Desertification (UNCCD, 2016). The dynamics of the Earth's biomass cover, or standing biomass, is a good expression of its potential to continue supplying ecosystem services (Dengiz, 2017). This study presents the land productivity dynamics for the study area as generated from satellite images based on the interactions of three NDVI-based indicators: steadiness, initial standing biomass, and standing biomass at change (https://earthmap.org/). The results show that $76.7 \%$ of the total land area of the North Wello Zone falls under the category of stable and not stressed land productivity, increasing land productivity, and stable but stressed land productivity class. The aerial distribution of this productivity class is mostly prevalent in the high and midlands where annual precipitation is not variable in terms of intensity, duration, and timing. The remaining $23.3 \%$ of the land falls either on the early sign of decline productivity or declining productivity. The study also considers that this type of land class is more likely in the lowlands in the eastern parts of the study area. The implication is for the urgent need of drought-specific land management practices in that particular area.

Third, the area with high soil organic carbon content was identified and mapped for the North Wello Zone. The results indicated that the maximum soil organic matter measured at $30 \mathrm{~cm}$ depth was 248.9 tons per hectare, and the minimum was 10 tons per hectare. The soil organic carbon in the study area is observed in the high and midland vegetation areas. The lowlands are very thin in soil organic content. The highest amount of carbon in the soil is an indicator of a stable ecosystem.

To summarize, the results of this study using the three UN indicators, the land use of the forest is showing an increasing trend, whilst the wetland is stable in the most recent period. The settlement area also shows a dramatic increase. Its increment is mostly at the expense of croplands. The grasslands, shrublands, and bare lands are showing a decreasing trend during 2010 to 2020. 
Although the NDVI value did not show significant variations across time and space, the land productivity dynamics derived from NDVI products show spatial variations. The organic content estimated in this area is consistent with the land productivity class. Thus, the findings revealed that most of the mid and highlands areas have relatively healthy environments. However, lowlands based on the three LDN indicators are highly degraded. The most troubling issue is large populations inhabiting the lowland areas of Raya Kobo and Habru districts that are practicing very intensive crop and livestock production.

This study suggested that land degradation is not uniform, even in the same administrative areas; nevertheless, an overall consensus seems to grow on the fact that many lands are under rehabilitation. The change is due to current policies on natural resource management in the country. To combat land degradation and sustainably increase land productivity on degraded land through sustainable land use, the current management approaches should be improved and supported by well-organized institutions and knowledge-based decision making by experts. In this regard, we believe that our results will be helpful as a source of information for local decision-makers in the North Wello Zone for evaluating policies regarding land-use changes and establishing guidelines and plans for actions to achieve land degradation neutrality in the future.

\section{Conclusion}

This study evaluates the different land management programs that are carried out in the region for a decade based on UNCCD land degradation neutrality indicators. The results show significant land use/ land cover changes over the study period. The settlement areas dramatically increased mostly at the expense of arable land in the study area. Settlement expansion without proper planning of land use will cost ecological, social, and environmental services. The forest cover in the study period shows both declining and increasing trends, but the most recent trend of forest cover is encouragingly positive. The grassland and croplands show decreasing trends while wetlands are at the state of balance in the most recent record. The land productivity conditions (net primary production) or NDVI and soil organic carbon content is highly prevalent in the forest lands of the high and midlands of the study area. The current land rehabilitation endeavor under the watershed development programs in many high and midland areas shows encouraging effects. However, in lowland areas, the land management programs and strategies should be contextually suitable to improve the land productivity conditions.

\section{References}

Abebe, G., Tsunekawa, A., Haregeweyn, N., Takeshi, T., Wondie, M., Adgo, E., ... \& Tassew, A. (2020). Effects of Land Use and Topographic Position on Soil Organic Carbon and Total Nitrogen Stocks in Different Agro-Ecosystems of the Upper Blue Nile Basin. Sustainability, 12(6), 2425.

Abegaz, A., Tamene, L., Abera, W., Yaekob, T., Hailu, H., Nyawira, S. S., ... \& Sommer, R. (2020). Soil organic carbon dynamics along chrono-sequence land-use systems in the highlands of Ethiopia. Agriculture, Ecosystems \& Environment, 300, 106997.

Abera, W., Tamene, L., Tibebe, D., Adimassu, Z., Kassa, H., Hailu, H., ... \& Verchot, L. (2020). Characterizing and evaluating the impacts of national land restoration initiatives on ecosystem services in Ethiopia. Land Degradation \& Development, 31(1), 37-52.

Assessment, M. E. MEA. 2005. Ecosystems and Human Well-Being: Synthesis. World Resources Institute, Washington, DC. 
Belay, T., \& Mengistu, D. A. (2019). Land use and land cover dynamics and drivers in the Muga watershed, Upper Blue Nile basin, Ethiopia. Remote Sensing Applications: Society and Environment, 15, 100249.

Berihun, M. L., Tsunekawa, A., Haregeweyn, N., Meshesha, D. T., Adgo, E., Tsubo, M., ... \& Yibeltal, M. (2019). Exploring land use/land cover changes, drivers and their implications in contrasting agro-ecological environments of Ethiopia. Land Use Policy, 87, 104052.

Bewket, W. (2002). Land cover dynamics since the 1950s in Chemoga watershed, Blue Nile basin, Ethiopia. Mountain research and development, 22(3), 263-269.

Bewket, W., \& Abebe, S. (2013). Land-use and land-cover change and its environmental implications in a tropical highland watershed, Ethiopia. International journal of environmental studies, 70(1), 126-139.

Bishaw, B. (2001). Deforestation and land degradation in the Ethiopian highlands: a strategy for physical recovery. Northeast African Studies, 7-25.

Cha, S., Kim, C. B., Kim, J., Lee, A. L., Park, K. H., Koo, N., \& Kim, Y. S. (2020). Land-use changes and practical application of the land degradation neutrality (LDN) indicators: a case study in the subalpine forest ecosystems, Republic of Korea. Forest Science and Technology, 16(1), 8-17.

Cherlet, M., Ivits, E., Sommer, S., Toyh, G., Jones, A., Montanaraella, L., \& Belward, A. (2013). Land-productivity dynamics in Europe. Towards valuation of land degradation in the EU, 61.

Conway, D. (2000). Some aspects of climate variability in the north east Ethiopian HighlandsWollo and Tigray. Sinet: Ethiopian Journal of Science, 23(2), 139-161.

Cowie, A. L., Orr, B. J., Sanchez, V. M. C., Chasek, P., Crossman, N. D., Erlewein, A., ... \& Tengberg, A. E. (2018). Land in balance: The scientific conceptual framework for Land Degradation Neutrality. Environmental Science \& Policy, 79, 25-35.

Damene, S., Bahir, A., \& Villamor, G. B. (2020). The role of Chomo grass (Brachiaria humidicola) and exclosures in restoring soil organic matter, total nitrogen, and associated functions in degraded lands in Ethiopia. Regional Environmental Change, 20(3), 1-13.

Damene, S., Tamene, L., \& Vlek, P. L. (2013). Performance of exclosure in restoring soil fertility: a case of Gubalafto district in North Wello Zone, northern highlands of Ethiopia. Catena, 101, 136-142.

Dengiz, O. (2018). Potential impact of land use change on land productivity dynamics with focus on land degradation in a sub-humid terrestrial ecosystem. Theoretical and Applied Climatology, 133(1-2), 73-88.

Elias, E., \& Fantaye, D. (2000). Managing fragile soils: A case study from North Wollo, Ethiopia. London, UK: IIED.

FAO. (2013). Climate smart agriculture source book. Food and Agriculture Organizations of United States, Rome Italy,2013

FAO. Food and Agriculture Organization. (2011). The state of food insecurity in the world: how does international price volatility affect domestic economies and food security?

Gashaw, T. (2015). The implications of watershed management for reversing land degradation in Ethiopia. Research Journal of Agriculture and Environmental Management, 4(1), 5-12.

Gashaw, T., Bantider, A., \& Mahari, A. (2014). Evaluations of land use/land cover changes and land degradation in Dera District, Ethiopia: GIS and remote sensing-based analysis. International Journal of Scientific Research in Environmental Sciences, 2(6), 199. 
Girma, D., Wogi, L., \& Feyissa, S. (2020). Effect of Land use Types on Soil Organic Carbon Stock at Sire Morose Sub Watershed, Hidabu Abote District of North Shoa Zone, Central Highland of Ethiopia. Science Research, 8(1), 1.

Grainger, A. (2015). Is land degradation neutrality feasible in dry areas?. Journal of Arid Environments, 112, 14-24.

Haregeweyn, N., Fikadu, G., Tsunekawa, A., Tsubo, M., \& Meshesha, D. T. (2012). The dynamics of urban expansion and its impacts on land use/land cover change and small-scale farmers living near the urban fringe: A case study of Bahir Dar, Ethiopia. Landscape and urban planning, 106(2), 149-157.

Henry, B., McKeon, G., Syktus, J., Carter, J., Day, K., \& Rayner, D. (2007). Climate variability, climate change and land degradation. In Climate and land degradation (pp. 205-221). Springer, Berlin, Heidelberg.

Hidalgo, C., Merino, A., Osorio-Hernández, V., Etchevers, J. D., Figueroa, B., Limon-Ortega, A., \& Aguirre, E. (2019). Physical and chemical processes determining soil organic matter dynamics in a managed vertisol in a tropical dryland area. Soil and Tillage Research, 194, 104348.

Holden, S., Shiferaw, B., \& Pender, J. (2004). Non-farm income, household welfare, and sustainable land management in a less-favoured area in the Ethiopian highlands. Food policy, 29(4), 369-392.

Hurni, H. (1988). Degradation and conservation of the resources in the Ethiopian highlands. Mountain research and development, 123-130.

Hurni, H., Abate, S., Bantider, A., Debele, B., Ludi, E., Portner, B., ... \& Zeleke, G. (2010). Land degradation and sustainable land management in the highlands of Ethiopia.

IPCC (2007): Climate change the physical science basis. AGUFM, 2007, U43D-01.

IPCC (2019). Land: An IPCC Special Report on climate change, desertification, land degradation, sustainable land management, food security, and greenhouse gas fluxes in terrestrial ecosystems. 2019. In The approved Summary for Policymakers (SPM) was presented at a press conference on (Vol. 8).

Jirata, M., Grey, S., \& Kilawe, E. (2016). Ethiopia climate-smart agriculture scoping study. FAO, Rome.

Kassie, M., Zikhali, P., Pender, J., \& Köhlin, G. (2010). The economics of sustainable land management practices in the Ethiopian highlands. Journal of agricultural economics, 61(3), 605-627.

Kust, G., Andreeva, O., \& Cowie, A. (2017). Land Degradation Neutrality: Concept development, practical applications and assessment. Journal of environmental management, 195, 16-24.

Mannava, V. K., \& Ndegwa (Ed.) Ndiang'ui. (2007). Climate and land degradation. Springer.

Meaza, H., Tsegaye, D., \& Nyssen, J. (2016). Allocation of degraded hillsides to landless farmers and improved livelihoods in Tigray, Ethiopia. Norsk Geografisk Tidsskrift-Norwegian Journal of Geography, 70(1), 1-12.

Nega, W., Hailu, B. T., \& Fetene, A. (2019). An assessment of the vegetation cover change impact on rainfall and land surface temperature using remote sensing in a subtropical climate, Ethiopia. Remote Sensing Applications: Society and Environment, 16, 100266.

Okpara, U. T., Stringer, L. C., Akhtar-Schuster, M., Metternicht, G. I., Dallimer, M., \& RequierDesjardins, M. (2018). A social-ecological systems approach is necessary to achieve land degradation neutrality. Environmental science \& policy, 89, 59-66. 
Palombi, L., \& Sessa, R. (2013). Climate-smart agriculture: sourcebook. Climate-smart agriculture: sourcebook.

Reed, M. S., \& Stringer, L. C. (2016). Land degradation, desertification and climate change: Anticipating, assessing and adapting to future change. Routledge.

Reid, R. S., Kruska, R. L., Muthui, N., Taye, A., Wotton, S., Wilson, C. J., \& Mulatu, W. (2000). Land-use and land-cover dynamics in response to changes in climatic, biological and sociopolitical forces: the case of southwestern Ethiopia. Landscape Ecology, 15(4), 339-355.

Safriel, U. (2017). Land Degradation Neutrality (LDN) in drylands and beyond-where has it come from and where does it go. Silva Fennica, 51(1B), 20-24.

Sanz, M. J., De Vente, J. L., Chotte, J. L., Bernoux, M., Kust, G., Ruiz, I., ... \& Hebel, A. (2017). Sustainable land management contribution to successful land-based climate change adaptation and mitigation: A report of the science-policy interface.

Scherr, S. J., Shames, S., \& Friedman, R. (2012). From climate-smart agriculture to climate-smart landscapes. Agriculture \& Food Security, 1(1), 12.

SD Shiene (2012). "Effectiveness of soil and water conservation measures for land restoration in the Wello area, northern Ethiopian highland." $\mathrm{PhD}$ diss., Universitäts-und Landesbibliothek Bonn, 2012.

Searchinger, T., Hanson, C., Ranganathan, J., Lipinski, B., Waite, R., Winterbottom, R., ... \& Dumas, P. (2014). Creating a sustainable food future. A menu of solutions to sustainably feed more than 9 billion people by 2050. World resources report 2013-14: interim findings.

Sivakumar, M. V., \& Ndiang'Ui, N. (Eds.). (2007). Climate and land degradation. Springer Science \& Business Media.

Stockmann, U., Adams, M. A., Crawford, J. W., Field, D. J., Henakaarchchi, N., Jenkins, M., ... $\&$ Wheeler, I. (2013). The knowns, known unknowns and unknowns of sequestration of soil organic carbon. Agriculture, Ecosystems \& Environment, 164, 80-99.

Sun, W., Zhu, H., \& Guo, S. (2015). Soil organic carbon as a function of land use and topography on the Loess Plateau of China. Ecological Engineering, 83, 249-257.

Sun, W., Zhu, H., \& Guo, S. (2015). Soil organic carbon as a function of land use and topography on the Loess Plateau of China. Ecological Engineering, 83, 249-257.

Taddese, G. (2001). Land degradation: a challenge to Ethiopia. Environmental management, 27(6), 815-824.

Teketay, D. (2001). Deforestation, wood famine, and environmental degradation in Ethiopia's highland ecosystems: urgent need for action. Northeast African Studies, 53-76.

Tengberg, A., \& Torheim, S. I. B. (2007). The role of land degradation in the agriculture and environment nexus. In Climate and Land Degradation (pp. 267-283). Springer, Berlin, Heidelberg.

Thiombiano, L., \& Tourino-Soto, I. (2007). Status and trends in land degradation in Africa. In Climate and land degradation (pp. 39-53). Springer, Berlin, Heidelberg.

Tolessa, T., Senbeta, F., \& Kidane, M. (2017). The impact of land use/land cover change on ecosystem services in the central highlands of Ethiopia. Ecosystem services, 23, 47-54.

UNCCD (2012): Zero Net Land Degradation UNCCD secretariat Recommendations for Policymakers,MMay 2012

UNCCD (2015): Climate change and land degradation: Bridging knowledge and stakeholders: Outcomes from the UNCCD 3rd Scientific Conference 
UNCCD (2016): Land Degradation Neutrality Target Setting Programme. Draft for consultation during the Land Degradation Neutrality Target Setting Programme inception phase, May 2016

Webb, N. P., Marshall, N. A., Stringer, L. C., Reed, M. S., Chappell, A., \& Herrick, J. E. (2017). Land degradation and climate change: building climate resilience in agriculture. Frontiers in Ecology and the Environment, 15(8), 450-459.

Winterbottom, R., Reij, C., Garrity, D., Glover, J., Hellums, D., McGahuey, M., \& Scherr, S. (2013). Improving land and water management. World Resources Institute Working Paper). Accessed on April, 2, 2014.

Woolf, D., Solomon, D., \& Lehmann, J. (2018). Land restoration in food security programmes: synergies with climate change mitigation. Climate Policy, 18(10), 1260-1270.

Wubneh, M. (2018). Policies and praxis of land acquisition, use, and development in Ethiopia. Land Use Policy, 73, 170-183.

Yang, H., Yuan, Y., Zhang, Q., Tang, J., Liu, Y., \& Chen, X. (2011). Changes in soil organic carbon, total nitrogen, and abundance of arbuscular mycorrhizal fungi along a large-scale aridity gradient. Catena, 87(1), 70-77.

Yirgu, L., Nicol, A., \& Srinivasan, S. (2013). Warming to change? climate policy and agricultural development in Ethiopia. Working paper 071. Future Agricultures consortium, Addis Ababa, Ethiopia. view at.

Zeleke, G., \& Hurni, H. (2001). Implications of land use and land cover dynamics for mountain resource degradation in the Northwestern Ethiopian highlands. Mountain research and development, 21(2), 184-191. 